\title{
Mapping of the Retrotransposable Elements Rex1 and Rex3 in Chromosomes of Eigenmannia (Teleostei, Gymnotiformes, Sternopygidae)
}

\author{
Viviani F. de Sene ${ }^{a}$ José C. Pansonato-Alves ${ }^{a}$ Daniela C. Ferreira ${ }^{b}$ \\ Ricardo Utsunomia ${ }^{a}$ Claudio Oliveira $^{\text {a }}$ Fausto Foresti $^{a}$ \\ a Laboratório de Biologia e Genética de Peixes, Instituto de Biociências de Botucatu, Universidade Estadual Paulista \\ (UNESP), Botucatu, and ${ }^{b}$ Laboratório de Genética Animal, Instituto de Biociências, Departamento de Biologia e \\ Zoologia, Universidade Federal de Mato Grosso (UFMT), Cuiabá, Brazil
}

\section{Key Words}

Heterochromatin - Molecular markers - Retrotransposons .

$\operatorname{Rex} 1 \cdot \operatorname{Rex} 3 \cdot \operatorname{Sex}$ chromosomes $\cdot$ Transposable elements

\begin{abstract}
Transposable elements constitute a remarkable fraction of the eukaryote genome and show particular capacity to move and insert in specific regions of the genome. This study identified the retrotransposable elements $\operatorname{Rex} 1$ and $\operatorname{Rex} 3$ in the genomes of 6 cytotypes of Eigenmannia. The sequences were isolated by $\mathrm{PCR}$, sequenced and physically mapped in the chromosomes of these cytotypes, aiming to investigate the organization and distribution of these elements in this fish group, mainly in the sex chromosomes. The FISH physical mapping revealed that both Rex 1 and Rex3 elements are dispersed in small clusters throughout the chromosomes of all cytotypes analyzed. However, conspicuous blocks occur in several samples, including an accentuated accumulation of the Rex 3 element in $\mathrm{X}_{1}$ and $\mathrm{X}_{2}$ chromosomes of Eigenmannia sp. 2 and in the $X$ chromosome of $E$. virescens. The accumulations are coincident with heterochromatin-rich regions, suggesting that Rex 3 played a role in the differentiation process of the sex chromosomes.

(c) 2015 S. Karger AG, Basel
\end{abstract}

Eukaryotic genomes contain a substantial amount of repetitive DNA, which includes the transposable elements (TEs) [Charlesworth et al., 1994]. TEs are divided into 2 classes: the transposons, which move as DNA molecules to other genome sites, and the retrotransposons, which move through an intermediate RNA that is reversely transcribed [Charlesworth et al., 1994]. Due to their mobile capacity, TEs may generate structural alterations in the insertion sites, which could lead to changes in chromosome structure or gene expression [Capy et al., 1998].

TEs can be visualized in chromosomes through fluorescent in situ hybridization (FISH) because of their repetitive nature [Oliveira et al., 1999]. The retrotransposable elements Rex 1 and Rex3 were mapped in several fish species [review in Ferreira et al., 2011b]. However, due to the extensive diversity of fishes, there is still a considerable lack of information about the distribution pattern of these elements, especially considering their potential role in (1) the dispersion of other repetitive elements [Mandrioli and Manicardi, 2001; Cioffi et al., 2009; Nakajima et al., 2012; Pansonato-Alves et al., 2013], (2) the evolution of sex chromosomes [Charlesworth et al., 2005; Fraser and Heitman, 2005], and (3) the occurrence of chromosomal rearrangements [Gray, 2000; Casals et al., 2003].

\section{KARGER 125}

(c) 2015 S. Karger AG, Base

$1424-8581 / 15 / 1464-0319 \$ 39.50 / 0$

E-Mail karger@karger.com

www.karger.com/cgr
Viviani França de Sene

Laboratório de Biologia e Genética de Peixes, Instituto de Biociências de Botucatu Universidade Estadual Paulista (UNESP), Departamento de Morfologia Distrito de Rubião Junior, Botucatu, SP 18618-970 (Brazil)

E-Mail sene@ibb.unesp.br 
Fishes of the genus Eigenmannia are widely distributed in South and Central America and are currently represented by 8 nominal species. However, a great number of species belonging to this genus has already been reported but not yet taxonomically described. The formerly described species probably constitute groups of cryptic species [Albert, 2001; Moysés et al., 2010]. Cytogenetic data available on Eigenmannia show a high karyotypic diversity with variations in the diploid number from 28 to 38 chromosomes, with several morphologically differentiated sex chromosome systems [Almeida-Toledo et al., 1985, 1996; Almeida-Toledo and Foresti, 2001].

As indicated above, TEs might be responsible for a large fraction of the karyotypic variations [Kidwell, 2005]. Also, the physical mapping of TEs in fish chromosomes can provide significant information regarding their organization and evolutionary dynamics. In the present study, we report on the constitution and distribution of the retrotransposable elements Rex 1 and Rex3 in the chromosomes of 6 Eigenmannia cytotypes.

\section{Materials and Methods}

\section{Samples}

Six Eigenmannia cytotypes were analyzed (Eigenmannia sp., Eigenmannia sp. 1, Eigenmannia sp. 2, E. cf. trilineata, and 2 karyomorphs of E. virescens). Samples were obtained in the Grande, Tietê, Paranapanema and Amazon river basins, as described in Sene et al. [2014]. The sample collections were conducted in accordance with the Brazilian environmental protection legislation (Collection Permission MMA/IBAMA/SISBIO, number 3245). The procedures for collection, maintenance and analysis of fish samples were performed in concordance with the international protocols on animal experimentation followed by the Universidade Estadual Paulista. The analyzed samples were fixed in $10 \%$ formaldehyde, preserved in $70 \%$ ethanol, identified, and deposited in the collection of the Laboratório de Biologia e Genética de Peixes, UNESP, Botucatu, São Paulo, Brazil, under the identification numbers LBP 12303-12308.

\section{TE Isolation and Sequencing}

Genomic DNA of each cytotype was obtained from liver or muscle samples preserved in ethanol using the Wizard Genomic DNA Purification Kit (Promega) according to the manufacturer's instructions. Partial sequences of the retrotransposable elements were amplified by PCR with the primers for Rex1: RTX1-F1 ( $5^{\prime}-$ TTCTCCAGTGGCCTTCAACACC-3'), RTX1-R1 (5'-TTCCTTAAAAAATAGAGTCTGCTC-3'), and Rex3: RTX3-F1 (5'-TACGGAGAAAACCCATTTCG-3') and RTX3-R1 (5'-AAAGTTCCTCGGTGGCAGG-3') [Volff et al., 1999, 2000]. The PCRs were run using $8.9 \mu \mathrm{l}$ of Mili-Q water, $1.25 \mu \mathrm{l}$ of Taq polymerase enzyme buffer $(10 \times), 0.5 \mu \mathrm{l}$ of $\mathrm{MgCl}_{2}(25 \mathrm{mM}), 0.25 \mu \mathrm{l}$ of dNTP $(2 \mathrm{mM}$ each), $0.25 \mu \mathrm{l}$ of each primer $(10 \mathrm{mM}), 0.1 \mu \mathrm{l}$ of Taq polymerase $(5 \mathrm{U} / \mu \mathrm{l})$, and $1 \mu \mathrm{l}$ of genomic DNA $(100 \mathrm{ng} / \mu \mathrm{l})$, for a total reaction volume of $12.5 \mu \mathrm{l}$. The PCR program involved the following steps: an initial denaturation at $95^{\circ} \mathrm{C}$ for $5 \mathrm{~min}$ followed by 35 cycles at $95^{\circ} \mathrm{C}$ for $45 \mathrm{~s}, 57^{\circ} \mathrm{C}$ for $45 \mathrm{~s}$ and $72^{\circ} \mathrm{C}$ for $5 \mathrm{~min}$. PCR products were checked on a $1 \%$ agarose gel. PCR fragments were purified using exonuclease and alkaline phosphatase enzymes (ExoSAP) and sequenced with the BigDye Terminator v3.1 Cycle Sequencing Kit (Applied Biosystems) in an automatic sequencer ABI $3130 \mathrm{Ge}$ netic Analyzer PRIS (Applied Biosystems).

\section{Chromosome Preparations and FISH Experiments}

Mitotic chromosomes were obtained applying the protocol of Foresti et al. [1981] and subjected to FISH according to Pinkel et al. [1986]. C-banding was performed following the protocol of Sumner [1972]. Additionally, the chromosomes were stained with DAPI, which can identify the AT-rich chromosome segments. In Eigenmannia, most heterochromatic bands are DAPI positive [Silva et al., 2009].

The probes used for FISH were labeled by PCR. The parameters used for labeling were: $18.2 \mu \mathrm{l}$ of water Mili-Q, $2.5 \mu \mathrm{l}$ of Taq polymerase enzyme buffer $(10 \times), 1 \mu$ of $\mathrm{MgCl}_{2}(25 \mathrm{mM}), 0.5 \mu \mathrm{l}$ of dNTP ( $2 \mathrm{mM}$ each), $0.5 \mu \mathrm{l}$ of digoxigenin-11-dUTP $(2 \mathrm{mM}), 0.5 \mu \mathrm{l}$ of each primer $(10 \mathrm{~mm}), 0.3 \mu \mathrm{l}$ of Taq polymerase $(5 \mathrm{U} / \mu \mathrm{l})$, and $1 \mu \mathrm{l}$ of genomic DNA (100 ng/ $\mu$ l). The PCRs were performed with a final volume of $25 \mu \mathrm{l}$. The PCR program comprised the following steps: an initial denaturation at $95^{\circ} \mathrm{C}$ for $5 \mathrm{~min}$ followed by 35 cycles at $95^{\circ} \mathrm{C}$ for $40 \mathrm{~s}, 55^{\circ} \mathrm{C}$ for $40 \mathrm{~s}$ and $72^{\circ} \mathrm{C}$ for $5 \mathrm{~min}$. PCR products were checked on a $1 \%$ agarose gel.

\section{Results}

All PCR experiments for the isolation of the elements Rex 1 and Rex3 were successful, and the sequences obtained showed good similarity with the Rex1 and Rex3 sequences deposited in GenBank (table 1). Sequences of Rex1 ranged from 390 to 564 bp and from 81 to $91 \%$ similarity, mainly with characiforms and cichlids. Sequences of Rex3 ranged from 103 to $415 \mathrm{bp}$ and 74 to $90 \%$ similarity, mainly with pufferfish, cichlids and cyprinids (table 1).

FISH experiments showed that the Rex 1 and Rex3 elements are organized in small clusters, including euchromatic and heterochromatic regions, in all samples analyzed (figs. 1, 2). However, considering that we used the same experimental hybridization conditions in all essays, the Rex3 element is more abundant than Rex1 (figs. 1, 2). In Eigenmannia sp. 2, there is a greater concentration of the elements Rex1 (fig. 1b) and Rex3 (fig. 2b) as compared to the other species analyzed. Additionally, Eigenmannia sp. 2, which has morphologically differentiated sex chromosomes with a multiple system of the type $\mathrm{X}_{1} \mathrm{X}_{1} \mathrm{X}_{2} \mathrm{X}_{2}$ / $\mathrm{X}_{1} \mathrm{X}_{2} \mathrm{Y}$, provided evidence of an accumulation of the element Rex3 in the chromosomes $\mathrm{X}_{1}$ and $\mathrm{X}_{2}$ (fig. 2b), coincident with heterochromatin-rich centromeric regions 
Table 1. Summary of the results obtained through Blast analyses of amplified PCR products in GenBank

\begin{tabular}{|c|c|c|c|c|c|c|}
\hline Species & PCR & $\begin{array}{l}\text { Base } \\
\text { pairs }\end{array}$ & $\begin{array}{l}\text { GenBank } \\
\text { number }\end{array}$ & Blast search & $\begin{array}{l}\text { Query } \\
\text { cover, \% }\end{array}$ & $\begin{array}{l}\text { Identity, } \\
\%\end{array}$ \\
\hline \multirow{2}{*}{$\begin{array}{l}\text { Eigenmannia sp. } 1 \\
(2 \mathrm{n}=28)\end{array}$} & $\operatorname{Rex} 1$ & 483 & KR780261 & Astyanax paranae non-LTR retrotransposon Rex 1 , partial & 88 & 86 \\
\hline & $\operatorname{Rex} 3$ & 103 & KR780268 & $\begin{array}{l}\text { Tetraodon nigroviridis non-LTR retrotransposon Rex3_Tet, } \\
\text { AJ621035.1 }\end{array}$ & 86 & 90 \\
\hline \multirow{2}{*}{$\begin{array}{l}\text { Eigenmannia sp. } 2 \\
(2 \mathrm{n}=31 / 32)\end{array}$} & $\operatorname{Rex} 1$ & 525 & KR780262 & Astyanax paranae non-LTR retrotransposon Rex1, partial & 60 & 89 \\
\hline & $\operatorname{Rex3}$ & 415 & KR780272 & $\begin{array}{l}\text { Astronotus ocellatus clone i non-LTR retrotransposon Rex3, } \\
\text { partial sequence, KF131700.1 }\end{array}$ & 49 & 81 \\
\hline \multirow{2}{*}{$\begin{array}{l}\text { E. cf. trilineata } \\
(2 \mathrm{n}=34)\end{array}$} & $\operatorname{Rex} 1$ & 390 & KR780264 & Astyanax paranae non-LTR retrotransposon Rex1, partial & 87 & 81 \\
\hline & $\operatorname{Rex} 3$ & 407 & KR780274 & $\begin{array}{l}\text { Geophagus proximus, retrotransposon Rex3, partial sequence, } \\
\text { KF131718.1 }\end{array}$ & 32 & 76 \\
\hline \multirow{2}{*}{$\begin{array}{l}\text { Eigenmannia sp. } \\
(2 \mathrm{n}=36)\end{array}$} & $\operatorname{Rex} 1$ & 564 & KR780265 & Symphysodon discus clone 2 non-LTR retrotransposon Rex1, & 97 & 91 \\
\hline & $\operatorname{Rex3}$ & 411 & KR780269 & $\begin{array}{l}\text { Cyprinus carpio genome assembly common carp genome, } \\
\text { scaffold } 000001853, \text { LN596728.1 }\end{array}$ & 92 & 74 \\
\hline \multirow{2}{*}{$\begin{array}{l}\text { E. virescens } \\
(2 \mathrm{n}=38)\end{array}$} & $\operatorname{Rex} 1$ & 530 & KR780266 & Astronotus ocellatus clone i non-LTR retrotransposon Rex3, & 83 & 87 \\
\hline & Rex3 & 411 & KR780270 & $\begin{array}{l}\text { Tetraodon nigroviridis non-LTR retrotransposon Rex3_Tet, } \\
\text { AJ621035.1 }\end{array}$ & 86 & 90 \\
\hline \multirow{2}{*}{$\begin{array}{l}\text { E. virescens } \\
(2 \mathrm{n}=38 \mathrm{XY})\end{array}$} & $\operatorname{Rex} 1$ & 564 & KR780267 & Astronotus ocellatus clone i non-LTR retrotransposon Rex3, & 97 & 91 \\
\hline & $\operatorname{Rex3}$ & 411 & KR780271 & $\begin{array}{l}\text { Tetraodon nigroviridis non-LTR retrotransposon Rex3_Tet, } \\
\text { AJ621035.1 }\end{array}$ & 91 & 74 \\
\hline
\end{tabular}

(fig. 3). In E. virescens XY chromosomes, Rex3 is more abundant on the $\mathrm{X}$ chromosome and coincident with the heterochromatic regions.

\section{Discussion}

Studies involving the structure and mapping of TEs in fish genomes are still scarce considering the great diversity of fish species. Data are currently available only for 32 species, and a total of 15 elements are already mapped. The existing studies show that these elements can be organized in different ways in diverse fish species [Ferreira et al., 2011a]. In all samples of Eigenmannia analyzed here, a dispersed pattern of the elements Rex1 and Rex3 was observed. Similar data were found in 3 species of Hypoptopomatinae [Ferreira et al., 2011b], in Erythrinus erythrinus [Cioffi et al., 2010], in Oreochromis niloticus [Valente et al., 2011], and in Triportheus trifurcatus [Yano et al., 2014] suggesting that this is a common pattern among fish.
The accumulation of TEs in the heterochromatin is a common characteristic in multicellular eukaryotes [HuaVan et al., 2005]. Since the selection pressure in this region is allegedly weaker, the heterochromatin would consequently work as a shelter for the TEs [Dimitri and Junakovic, 1999; Bartolomé et al., 2002; Da Silva et al., 2002]. Sene et al. [2014] investigated the C-band pattern in Eigenmannia using the same cytotypes studied here. Their results showed that species with the lowest diploid chromosome number have less heterochromatin and, in general, the heterochromatin is basically restricted to the centromeric regions of the chromosomes. The present study revealed that Rex 1 and Rex 3 sequences are common in the AT-rich chromosome regions (corresponding to the C-band regions), but are also present in other chromosome regions (figs. 1, 2).

However, in some cytotypes, as in Eigenmannia sp. 2, we found a very strong correlation between the distribution of Rex3 and C-band positive blocks (fig. 1b). The association of the TEs with the heterochromatic regions in many Eigenmannia chromosomes may reinforce their 

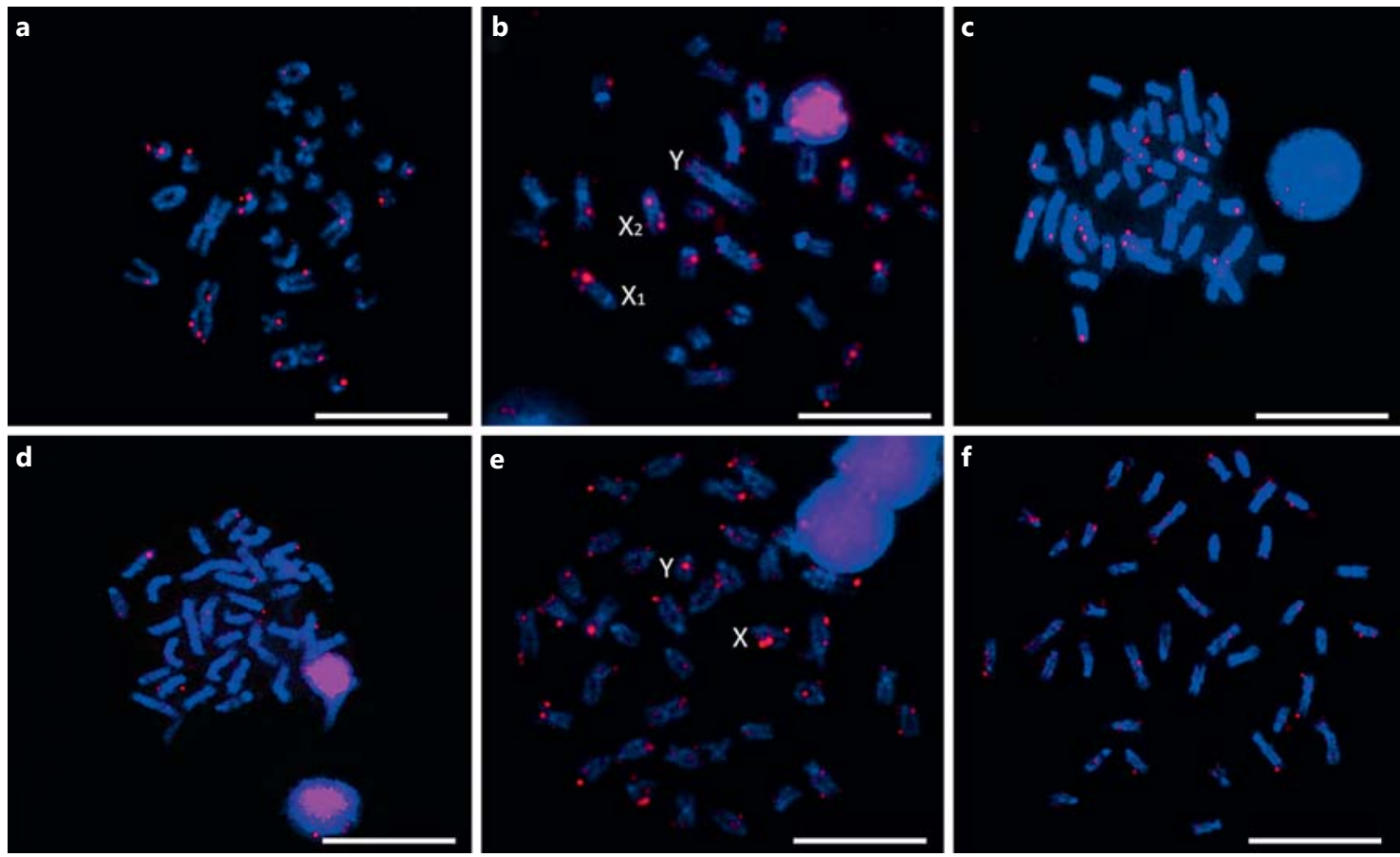

Fig. 1. Somatic metaphases of Eigenmannia showing dispersed distribution of Rex1. a Eigenmannia sp. 1, 2n = 28; b Eigenmannia sp. 2, $2 \mathrm{n}=31$ with $\mathrm{X}_{1} \mathrm{X}_{2} \mathrm{Y}$ multiple sex chromosomes; c Eigenman- nia cf. trilineata, $2 \mathrm{n}=34 ; \mathbf{d}$ Eigenmannia sp., $2 \mathrm{n}=36$; $\mathbf{e}$ E. virescens, $2 \mathrm{n}=38$ with XY sex chromosomes; $\mathbf{f}$ E. virescens, $2 \mathrm{n}=38$. Bars = $10 \mu \mathrm{m}$.
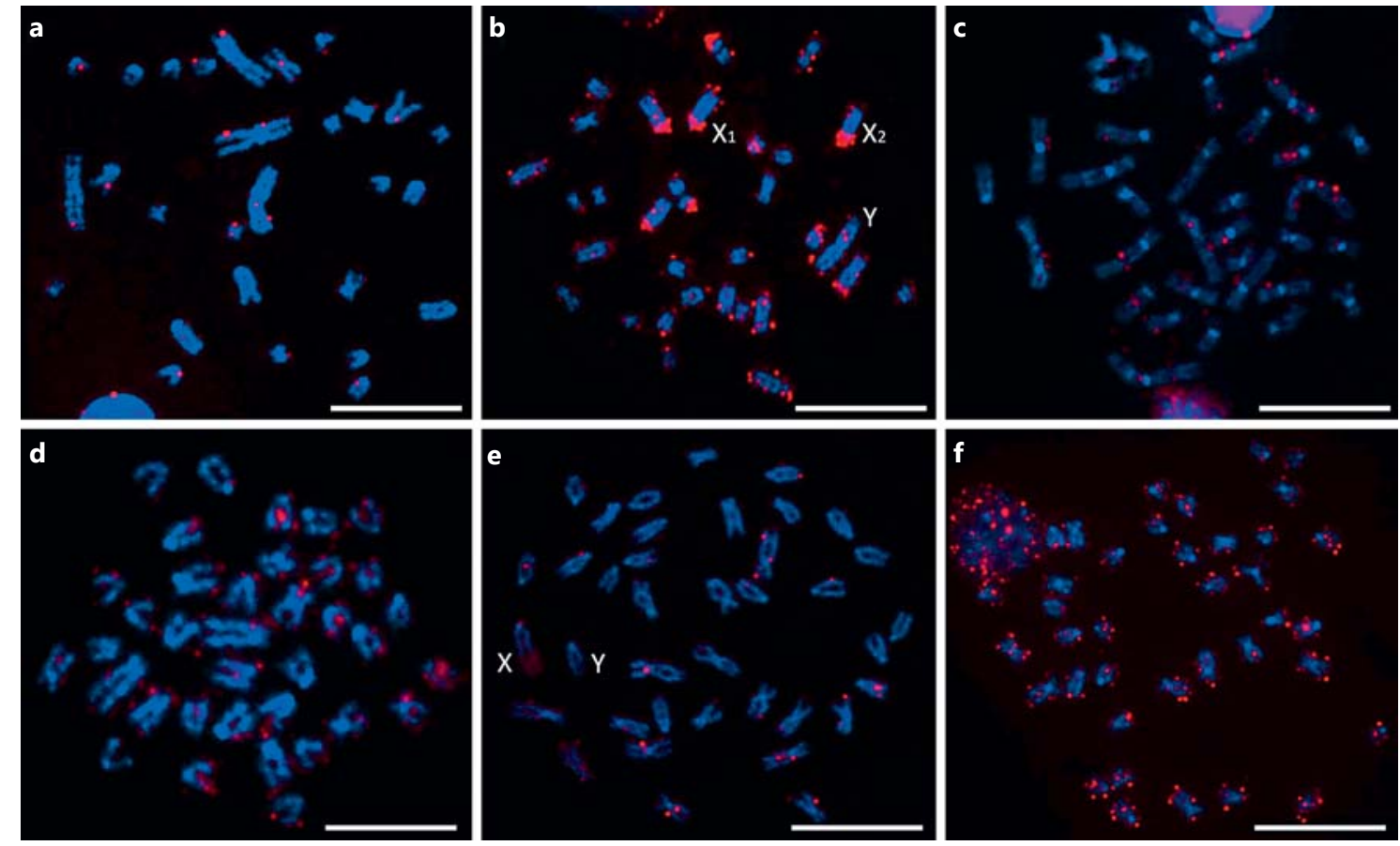

Fig. 2. Somatic metaphases of Eigenmannia showing dispersed distribution of Rex3. a Eigenmannia sp. 1, 2n = 28; b Eigenmannia sp. 2, $2 \mathrm{n}=31$ with $\mathrm{X}_{1} \mathrm{X}_{2} \mathrm{Y}$ multiple sex chromosomes; c Eigenmannia cf. trilineata, $2 \mathrm{n}=34$; d Eigenmannia sp., $2 \mathrm{n}=36$; e E. virescens,

$2 \mathrm{n}=38$ with $\mathrm{XY}$ sex chromosomes; $\mathbf{f}$ E. virescens, $2 \mathrm{n}=38$. In the $\mathrm{X}$ chromosomes of Eigenmannia sp. 2 and E. virescens the Rex 3 elements are concentrated forming strong clusters in the C-band positive segments. Bars $=10 \mu \mathrm{m}$. 
Fig. 3. Somatic metaphases of Eigenmannia showing conspicuous C-positive heterochromatin segments accumulated on the $\mathrm{X}$ chromosomes. a Eigenmannia sp. 2; b E. virescens. Bars $=10 \mu \mathrm{m}$.
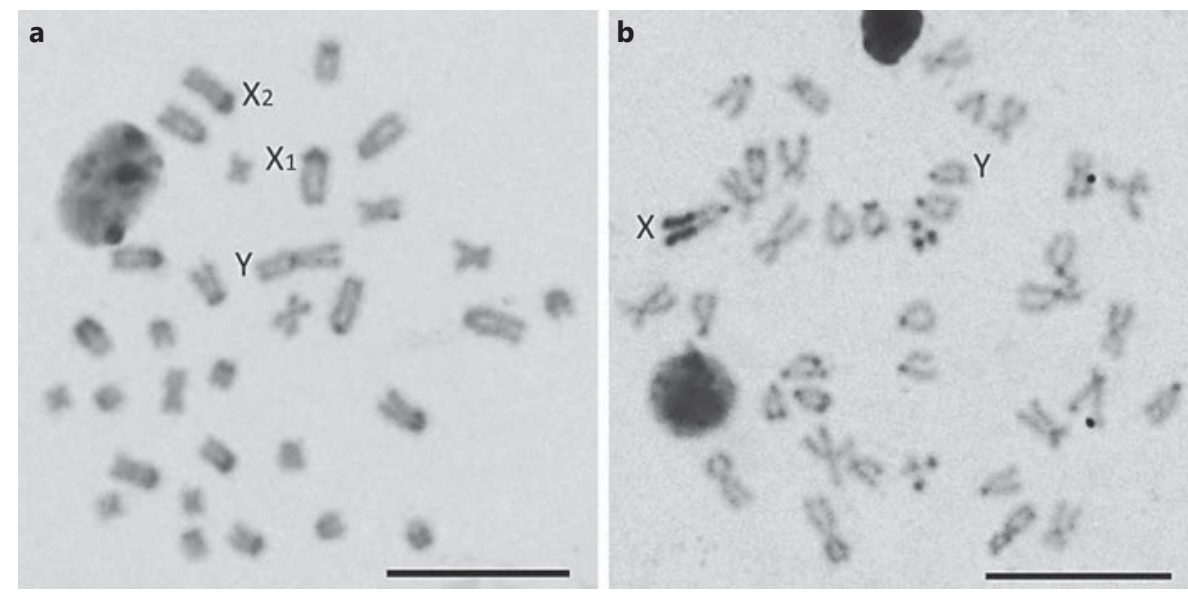

importance in the organization of these regions. It may also be related to the extensive changes in chromosome number and morphology observed in the genus, as suggested by Dimitri and Junakovic [1999] and Dawe [2003].

The importance of TEs in the evolution of sex chromosomes in eukaryote genomes has been observed in various organisms [Bachtrog, 2005; Charlesworth et al., 2005; Fraser and Heitman, 2005; Ming et al., 2007]. In Eigenmannia sp. 2, with $\mathrm{X}_{1} \mathrm{X}_{1} \mathrm{X}_{2} \mathrm{X}_{2} / \mathrm{X}_{1} \mathrm{X}_{2} \mathrm{Y}$ sex chromosome system, the C-band-positive blocks the $\mathrm{X}$ chromosomes show a visible amount of Rex 3 sequences (fig. $2 b$ ). The same is true for the $\mathrm{X}$ chromosome of $E$. virescens, but in this species the signal over the heterochromatin is weak (fig. 2e). On the other hand, the sequences of Rexl do not form clusters in sex chromosomes (fig. 1b, e). Several studies have suggested that TEs have a prominent role in the differentiation process of sex chromosomes. For example, in O. niloticus, the accumulation of many TEs in the sex chromosome pair is possibly related to the sexual differentiation process, evidencing the association of retroelements with chromosomal rearrangements, namely chromosome fusion [Oliveira et al., 1999; Harvey et al.,
2003; Valente et al., 2011]. A study of Rex3 in Chionodraco hamatus [Ozouf-Costaz et al., 2004] revealed an association of this element with a heterochromatic region located in the long arm of the $\mathrm{Y}$ chromosome involved in the chromosome fusion process that possibly originated it. Ozouf-Costaz et al. [2004] suggested that the accumulation mechanism of these elements possibly existed in autosomes before the occurrence of chromosomal rearrangements. Such an accumulation mechanism might potentially influence the modification processes involved in the organization of the heteromorphic sex chromosomes. The same observation may be true in Eigenmannia, but additional studies (including phylogenetic studies) should be conducted for a better understanding of their evolutionary history.

\section{Acknowledgements}

The authors thank Mr. Renato Devidé for the assistance in field and laboratory activities. This study was funded by FAPESP, CNPq and CAPES.

\section{References}

Albert JS: Species diversity and phylogenetic systematics of American knife fishes (Gymnotiformes-Teleostei). Misc Publ Mus Zool Univ Michigan 190:1-127 (2001).

-Almeida-Toledo LF, Foresti F: Morphologically differentiated sex chromosomes in Neotropical freshwater fish. Genetica 111:91-100 (2001).

-Almeida-Toledo LF, Foresti F, Toledo-Filho S: Spontaneous triploidy and NOR activity in
Eigenmannia sp. (Pisces, Sternopygidae) from the Amazon basin. Genetica 66:85-88 (1985).

Almeida-Toledo LF, Stocker AJ, Foresti F, Toledo-Filho SA: Fluorescence in situ hybridization with rDNA probes on chromosomes of two nucleolus organizer region phenotypes of a species of Eigenmannia (Pisces, Gymnotoidei, Sternopygidae). Chromosome Res 4:301305 (1996). 
Bachtrog D: Sex chromosome evolution: molecular aspects of Y-chromosome degeneration in Drosophila. Genome Res 15:1393-1401 (2005).

Bartolomé C, Maside X, Charlesworth B: On the abundance and distribution of transposable elements in the genome of Drosophila melanogaster. Mol Biol Evol 19:926-937 (2002).

Capy P, Bazin C, Higuet D, Langin T: Dynamics and Evolution of Transposable Elements (Landes Bioscience, Austin 1998).

-Casals F, Cáceres M, Ruiz A: The foldback-like transposon Galileo is involved in the generation of two different natural chromosomal inversions of Drosophila buzzatii. Mol Biol Evol 20:674-685 (2003).

Charlesworth B, Sniegowski P, Stephan W: The evolutionary dynamics of repetitive DNA in eukaryotes. Nature 371:215-220 (1994).

-Charlesworth D, Charlesworth B, Marais G: Steps in the evolution of heteromorphic sex chromosomes. Heredity 95:118-128 (2005).

-Cioffi MB, Martins C, Bertollo LAC: Comparative chromosome mapping of repetitive sequences. Implications for genomic evolution in the fish, Hoplias malabaricus. BMC Genet 10:3444 (2009).

Cioffi MB, Martins C, Vicari MR, Rebordinos L, Bertollo LAC: Differentiation of the XY sex chromosomes in the fish Hoplias malabaricus (Characiformes, Erythrinidae): unusual accumulation of repetitive sequences on the $\mathrm{X}$ chromosome. Sex Dev 4:176-185 (2010).

Da Silva C, Hadji H, Ozouf-Costaz C, Nicaud S, Jaillon O, et al: Remarkable compartmentalization of transposable elements and pseudogenes in the heterochromatin of the Tetraodon nigroviridis genome. Proc Natl Acad Sci USA 99:13636-13641 (2002).

Dawe RK: RNA interference, transposons and the centromere. Plant Cell 15:297-301 (2003).

Dimitri P, Junakovic N: Revising the selfish DNA hypothesis: new evidence on accumulation of transposable elements in heterochromatin. Trends Genet 15:123-124 (1999).

Ferreira DC, Porto-Foresti F, Oliveira C, Foresti $\mathrm{F}$ : Transposable elements as a potential source for understanding the fish genome. Mob Genet Elements 1:1-6 (2011a).
Ferreira DC, Oliveira C, Foresti F: Chromosome mapping of retrotransposable elements Rex 1 and Rex3 in three fish species in the subfamily Hypoptopomatinae (Teleostei, Siluriformes, Loricariidae). Cytogenet Genome Res 132:64-70 (2011b).

Foresti F, Almeida-Toledo LF, Toledo-Filho SA: Polymorphic nature of nucleolus organizer regions in fishes. Cytogenet Cell Genet 31: 137-144 (1981).

Fraser JA, Heitman J: Chromosomal sex-determining regions in animals, plants and fungi. Curr Opin Genet Dev 15:645-651 (2005).

Gray YHM: It takes two transposons to tango: transposable-element-mediated chromosomal rearrangements. Trends Genet 16:461468 (2000).

Harvey SC, Boonphakdee C, Campos-Ramos R, Ezaz MT, Griffin DK, et al: Analysis of repetitive DNA sequences in the sex chromosomes of Oreochromis niloticus. Cytogenet Genome Res 101:314-319 (2003).

Hua-Van A, Le Rouzic A, Maisonhaute C, Capy P: Abundance, distribution and dynamics of retrotransposable elements and transposons: similarities and differences. Cytogenet Genome Res 110:426-440 (2005).

Kidwell MG: Transposable elements, in Gregory TR (ed): The Evolution of the Genome, pp 165-221 (Elsevier, San Diego 2005).

Mandrioli M, Manicardi GC: Cytogenetic and molecular analysis of the pufferfish Tetraodon fluviatilis (Osteichthyes). Genetica 111:433438 (2001).

Ming R, Yu Q, Moore PH: Sex determination in papaya. Semin Cell Dev Biol 18:401-408 (2007).

Moysés CB, Daniel Silva MFZ, Lopes CE, Almeida-Toledo LF: Cytotype-specific ISSR profiles and karyotypes in the Neotropical genus $E i$ genmannia (Teleostei: Gymnotiformes). Genetica 138:179-189 (2010).

Nakajima RT, Cabral-de-Mello DC, Valente GT, Venere PC, Martins C: Evolutionary dynamics of rRNA gene clusters in cichlid fish. BMC Evol Biol 12:198 (2012).

Oliveira C, Chew JS, Porto-Foresti F, Dobson MJ, Wright JM: A LINE2 repetitive DNA sequence from the cichlid fish, Oreochromis niloticus. Sequence analysis and chromosomal distribution. Chromosoma 108:457-468 (1999).
Ozouf-Costaz C, Brandt J, Korting C, Pisano E, Bonillo C, et al: Genome dynamics and chromosomal localization of the non-LTR retrotransposons Rex 1 and Rex3 in Antarctic fish. Antarctic Sci 16:51-57 (2004).

-Pansonato-Alves JC, Serrano EA, Utsunomia R, Scacchetti PC, Oliveira C, Foresti F: Mapping five repetitive DNA classes in sympatric species of Hypostomus (Teleostei: Siluriformes: Loricariidae): analysis of chromosomal variability. Rev Fish Biol Fisheries 23:477-489 (2013).

Pinkel D, Straume T, Gray JW: Cytogenetic analysis using quantitative, high-sensitivity, fluorescence hybridization. Proc Natl Acad Sci USA 83:2934-2938 (1986)

-Sene VF, Pansonato-Alves JC, Utsunomia R, Oliveira C, Foresti F: Karyotype diversity and patterns of chromosomal evolution in Eigenmannia (Teleostei, Gymnotiformes, Sternopygidae). Comp Cytogenet 8:301-311 (2014).

$\checkmark$ Silva DS, Milhomem SSR, Pieczarka JC, Nagamachi CY: Cytogenetic studies in Eigenmannia virescens (Sternopygidae, Gymnotiformes) and new inferences on the origin of sex chromosomes in the Eigenmannia genus. BMC Genet 10:74-82 (2009).

Sumner AT: A simple technique for demonstrating centromeric heterochromatin. Exp Cell Res 75:304-306 (1972).

Valente GT, Mazzuchelli J, Ferreira IA, Poletto AB, Fantinatti BEA, Martins C: Cytogenetic mapping of the retroelements Rex $1, \operatorname{Rex} 3$ and Rex6 among cichlid fish: new insights on the chromosomal distribution of transposable elements. Cytogenet Genome Res 133:34-42 (2011).

Volff JN, Körting G, Sweeney K, Schartl M: The non-LTR retrotransposon Rex3 from the fish Xiphophorus is widespread among teleosts. Mol Biol Evol 16:1427-1438 (1999).

Volff JN, Körting C, Schartl M: Multiple lineages of the non-LTR retrotransposon Rex1 with varying success in invading fish genomes. Mol Biol Evol 17:1673-1684 (2000).

$\checkmark$ Yano CF, Poltronieri J, Bertollo LAC, Artoni RF, Liehr T, et al: Chromosomal mapping of repetitive DNAs in Triportheus trifurcatus (Characidae, Characiformes): insights into the differentiation of the $\mathrm{Z}$ and $\mathrm{W}$ chromosomes. PLoS One 9:e90946 (2014). 